\title{
Cellular Physiology

\section{The Closer we Look the more we See? Quantitative Microscopic Analysis of the Pulmonary Surfactant System}

\author{
Matthias Ochs ${ }^{1,2}$ \\ ${ }^{1}$ Institute of Anatomy, University of Bern, Bern, ${ }^{2}$ Institute of Functional and Applied Anatomy, Hannover \\ Medical School, Hannover
}

\section{Key Words \\ Lung - Alveoli - Type II cells - Lamellar bodies • Surfactant - Stereology Electron microscopy • Electron tomography}

\begin{abstract}
The surfactant system of the lung has essential biophysical and immunomodulatory functions. Only at the electron microscopic level does surfactant reveal its morphological complexity - and beauty. Therefore, morphological tools are indispensible to characterize the surfactant system in health and disease. Stereology provides the gold standard for obtaining quantitative (morphometric) data in microscopy. The combination of microscopy and stereology allows for qualitative and quantitative analysis of the intraalveolar as well as the intracellular surfactant pool, both in its preserved microorganization and localization within the lung. Surfactantproducing alveolar epithelial type II cells can be counted and sampled for size estimation with physical disectors at a high magnification light microscopic level. The number of their surfactant storing lamellar bodies can be estimated using physical disectors at the electron microscopic level. Electron tomography allows for high resolution 3D visualization of lamellar body fusion pores. Intraalveolar surfactant subtypes
\end{abstract}

\section{KARGER}

Fax +4161306 1234

E-Mail karger@karger.ch

www.karger.com
(C) 2010 S. Karger AG, Basel

$1015-8987 / 10 / 0251-0027 \$ 26.00 / 0$

Accessible online at: www.karger.com/cpb can be quantitated in situ, thus reflecting the functional state of the intraalveolar surfactant pool. By immunoelectron microscopy, surfactant protein distribution can be analyzed. These methods allow for a comprehensive quantitative analysis of surfactant (ultra-)structure. Here, we give an overview on the analysis of the normal and disordered surfactant system by electron microscopy and stereology.

Copyright (C) 2010 S. Karger AG, Basel

\section{Pulmonary surfactant}

Each day a human being inhales and exhales more than 10,000 liters of air. Within the lungs, the exchange surface for the diffusion of gases is distributed over about 300 to 500 million alveoli and is as large as $120-140 \mathrm{~m}^{2}$ (nearly the size of a tennis court). At the same time, the thickness of the exchange barrier is only about $2 \mu \mathrm{m}$ (50 times thinner than a sheet of air-mail stationary). This large and delicate surface has to be protected against collapse (i.e. atelectasis) as well as against invasion of pathogens. For both, biophysical and immunomodulatory, functions, the pulmonary surfactant system is principally responsible. Thus, the integrity of the pulmonary

Prof. Dr. Matthias Ochs

Institute of Functional and Applied Anatomy, Hannover Medical School Carl-Neuberg-Str. 1, D-30625 Hannover (Germany)

Tel. +49 511532 6741, Fax +49 5115322948

E-Mail ochs.matthias@mh-hannover.de 
surfactant system is essential for normal lung function (for review, see [1-6]). Basically, surfactant helps to keep the large alveolar surface of the lung open, dry, and clean.

Surfactant consists of about $90 \%$ lipids and about $10 \%$ proteins. The protein fraction includes the surfactantassociated proteins SP-A, -B, -C, and -D. Only at the level of electron microscopy (EM) does surfactant reveal its morphological complexity (reviewed in [7]). Surfactant is synthesized, stored, secreted, and to a large extent recycled by type II alveolar epithelial cells [8]. Thus, an intracellular surfactant pool present in type II cells and an intraalveolar surfactant pool present at the surface of the fluid alveolar lining layer as well as within its hypophase can be distinguished (Fig. 1). Synthesis of surfactant material involves endoplasmic reticulum, at least partly Golgi complex, multivesicular bodies, and composite bodies (Fig. 2). The vast majority of intracellular surfactant material (all lipids and the hydrophobic SP-B and $-\mathrm{C}$ ) is assembled in specific storage organelles, lamellar bodies, prior to secretion [9-11]. Intraalveolar surfactant consists of several subtypes. These include freshly secreted lamellar body-like forms, tubular myelin, the surface film, and small unilamellar vesicles. After secretion, lamellar body-like forms associate with SP-A and transform into lattice-like tubular myelin figures, which have been suggested to be precursors of the surface film although this has not been demonstrated directly. "Spent" surfactant components are found in the hypophase as small unilamellar vesicles that can be taken up either by type II cells for subsequent recycling or degradation or by alveolar macrophages for degradation. Therefore, intraalveolar surfactant subtypes that can be distinguished based on their morphology correspond to different functional stages in surfactant metabolism. In other words, the functional status of the surfactant system is directly reflected in intraalveolar surfactant subtype composition. This can either be assessed biochemically and biophysically using material obtained by bronchoalveolar lavage (BAL) (reviewed in [4, 12-14]) or morphologically by electron microscopy and stereology ([15]; see below).

The associated proteins are considered to be the "smart molecules" within the surfactant system [16], being involved in surfactant structural assembly, function (both biophysics and immunomodulation), and homeostasis. The hydrophilic surfactant proteins SP-A and SP-D are members of the collectin subfamily of C-type lectins. Collectins, pattern-recognition proteins with extended collagen-like domains linked to C-type lectin domains, participate in the innate immune response by both binding a wide variety of glycoconjugates and modulating immune



Fig. 1. Schematic illustration of surfactant metabolism. Surfactant components are synthesized in alveolar epithelial type II cells via transcription, translation at the rough endoplasmic reticulum (rER), posttranslational processing in the Golgi apparatus (Golgi) and further processing and transport in multivesicular bodies (MVB). Some surfactant components might bypass the Golgi apparatus and MVB. Surfactant lipid and the hydrophobic proteins SP-B and -C are assembled in so-called composite bodies (CB) sharing structural characteristics of MVB and mature lamellar bodies (LB). Surfactant is stored in LB and secreted by exocytosis. SP-A and SP-D are secreted via an alternative route by direct exocytosis of small vesicles and/or MVB. After exocytosis into the aqueous hypophase (HY), lamellar bodies are unpacked and form tubular myelin (TM) figures, from which the surface film (SF) can be generated. Hypophase and surface film are termed the alveolar lining layer (ALL). Surfactant that is removed from the air-liquid interface is either reused or degraded. "Spent" surfactant has the morphological appearance of unilamellar vesicles (UV) and can be taken up and degraded by alveolar macrophages (AM), be cleared via the airways or be taken up by type II cells. There the surfactant components may be degraded, enter de novo synthesis or be transported to $\mathrm{CB}$ or LB for resecretion. The surface active „large aggregates“ (LA) fraction of intraalveolar surfactant obtained by bronchioalveolar lavage largely corresponds to TM whereas the inactive „small aggregates“ (SA) fraction largely corresponds to UV. Reproduced with permission from [159].

\section{cell responses [6, 17-19].}

The crucial role of the surfactant system for the maintenance of the functional integrity of the lung is clearly demonstrated by surfactant dysfunction disorders, which can be caused either at birth by developmental deficiency (due to lung immaturity or due to mutations affecting synthesis, assembly, secretion or uptake of surfactant components) or later by acquired dysfunction (due to damage of type II cells or inhibition/inactivation of intraalveolar surfactant). A primary deficiency of 
surfactant in the immature lungs causes the respiratory distress syndrome of premature neonates (RDS) [20]. Impairment of an originally intact surfactant system is involved in the pathogenesis of a variety of other lung diseases, such as acute lung injury / acute respiratory distress syndrome (ARDS) as well as infectious, obstructive and interstitial lung diseases $[4,5,13,14]$.

\section{Ultrastructural and stereological analysis of surfactant}

Morphological tools are essential to characterize the surfactant system in health and disease. These include in particular EM-based methods and stereology. The high spatial resolution provided by EM is required to directly visualize and analyze surfactant. A variety of basic and advanced EM methods is available. Adequate fixation and processing methods (described in detail in [21-23]) have to be employed in order to preserve the phospholipidrich surfactant material for transmission EM investigation and thus to obtain reliable qualitative and quantitative data on surfactant ultrastructure. The intracellular and intraalveolar surfactant subtypes can then be visualized by conventional transmission EM (Fig. 3).

No method of tissue fixation for EM yields a "perfect" representation of lung structure. While in general, conventional chemical fixation for EM (based on glutaraldehyde and osmium tetroxide) results in good overall preservation of cell and tissue ultrastructure, the selective nature of the chemical interactions taking place during fixation, processing and dehydration may induce artifacts [24]. Therefore, morphological characteristics and differences observed in biological EM samples need to be interpreted with care and knowledge of the preparation steps involved. This is of particular importance in EM studies of surfactant because, due to its high amounts of saturated phospholipids, surfactant material can be extracted to a considerable degree, thereby e.g. resulting in "empty" lamellar bodies. One way to prevent this is based on phospholipid stabilization by prolonged bloc-staining with uranyl acetate prior to dehydration [22, 23] (Fig. 2, 3). Theoretically, the ideal method for near in-vivo preservation of ultrastructure is physical fixation by rapid freezing. For EM, the cooling conditions necessary to avoid artifacts (ice crystal formation) are achieved by high pressure freezing of small (thickness = $200 \mu \mathrm{m})$ samples [25]. However, applied to the lung, high pressure freezing would lead to collapse of alveoli unless they are filled with an appropriate fluid prior to fixation.

Quantitative Microscopy of Surfactant

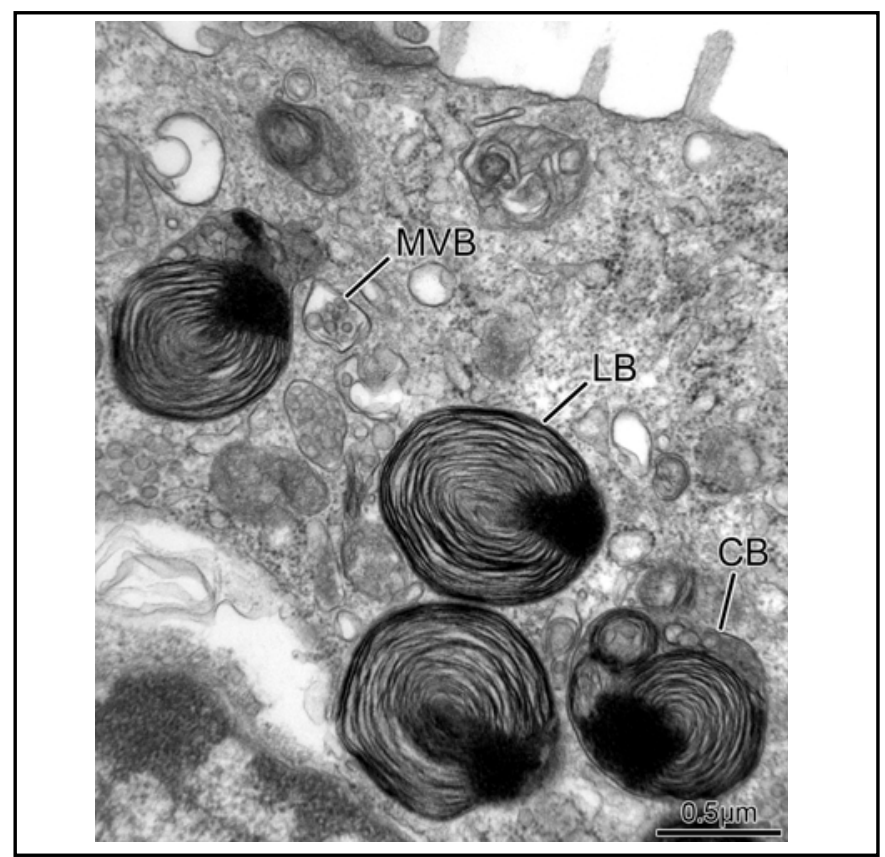

Fig. 2. Transmission electron micrograph of an alveolar epithelial type II cell in the human lung. Fixation by airway instillation. Phospholipid stabilization by bloc-staining with uranyl acetate (for details of the protocol, see 22, 23). The biosynthetic pathway of surfactant involves multivesicular bodies (MVB) and composite bodies (CB). Finally, the phospholipid-rich surfactant material is stored in lamellar bodies (LB) prior to secretion onto the alveolar epithelial surface.

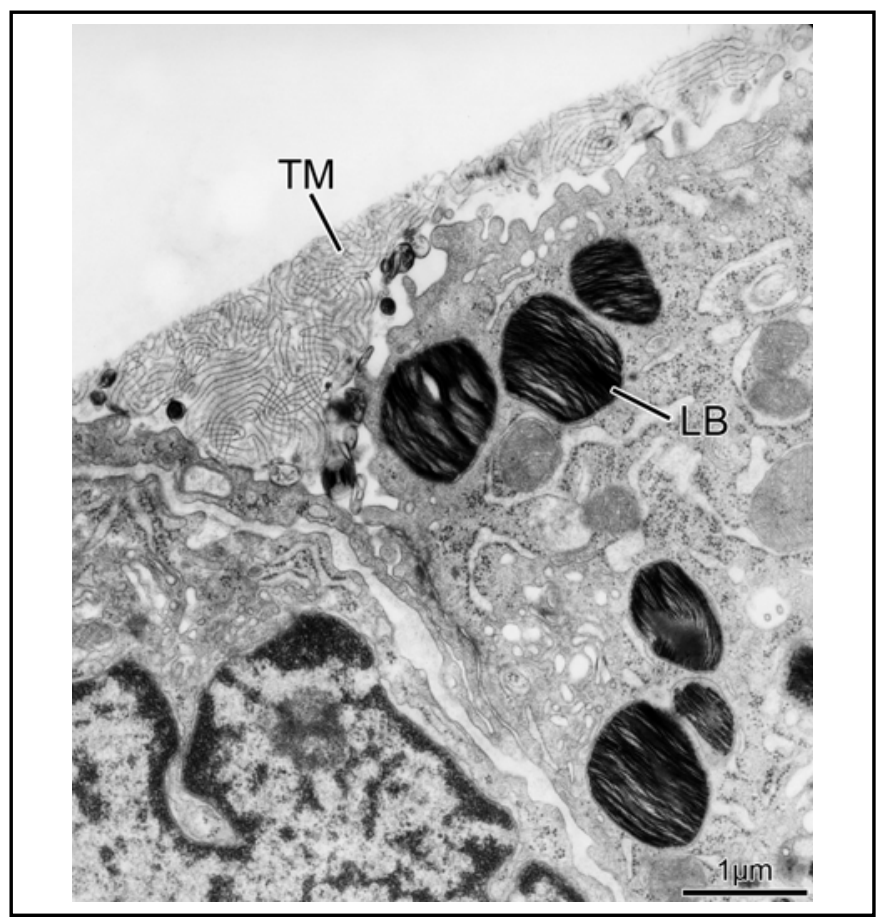

Fig. 3. Transmission electron micrograph of rat lung fixed by vascular perfusion. Both the intracellular surfactant pool (in lamellar bodies (LB) within type II cells) and the intraalveolar surfactant pool (here tubular myelin (TM) covering the alveolar epithelium) can be visualized.

Cell Physiol Biochem 2010;25:27-40 
Fig. 4. Comparison of lamellar body ultrastructure in the human (a) and rat (b) lung. Human lung lamellar bodies usually show a concentric arrangement of lamellae originating from a dense projection core (PC). Rodent lamellar bodies usually contain lamellae arranged as parallel stacks.



Moreover, this approach is, at least yet, not suitable for quantitative analysis of whole lungs by stereology (see below) because it precludes adequate sampling for which the whole (fixed) organ should be available. At current, this can only be achieved by chemical fixation under carefully controlled conditions, either by airway instillation or (in particular for intraalveolar surfactant) by vascular perfusion, both of which also fulfill the criteria of consistent reproducibility in space (homogeneity) and time (repeatability) [21]. Nevertheless, high pressure freezingbased cryopreparation methods hold great potential for qualitative EM studies of surfactant.

The presence of lamellar bodies is a characteristic feature of type II alveolar epithelial cells. In humans, a single type II cell contains about 200-500 lamellar bodies, whereas in mice one finds about 50-100 lamellar bodies per type II cell [26]. Notable species differences exist with respect to lamellar body ultrastructure. In the human lung, lamellar bodies are composed of concentrically arranged lamellae attached to a projection core which, depending on the section plane, is usually located at the periphery. The projection core contains densely stacked short membrane segments in a random orientation (Fig. 4a). In contrast, lamellar bodies of rodents do not contain a projection core, and their lamellae, again depending on the section plane, are usually arranged in parallel (Fig. 4b). Species differences in lamellar body ultrastructure have long been noted (e.g. [27-30]), but they are not always taken into consideration. However, these findings are mainly based on chemically fixed samples. Verification (or falsification) by cryo-electron microscopy of vitreous sections [31] therefore seems desirable. Interesting concepts regarding the formation of lamellar bodies with parallel or concentric arrangement of lamellae have been provided recently by Perez-Gil [32]. Remarkably, differences in the ultrastructural arrangement of lamellae

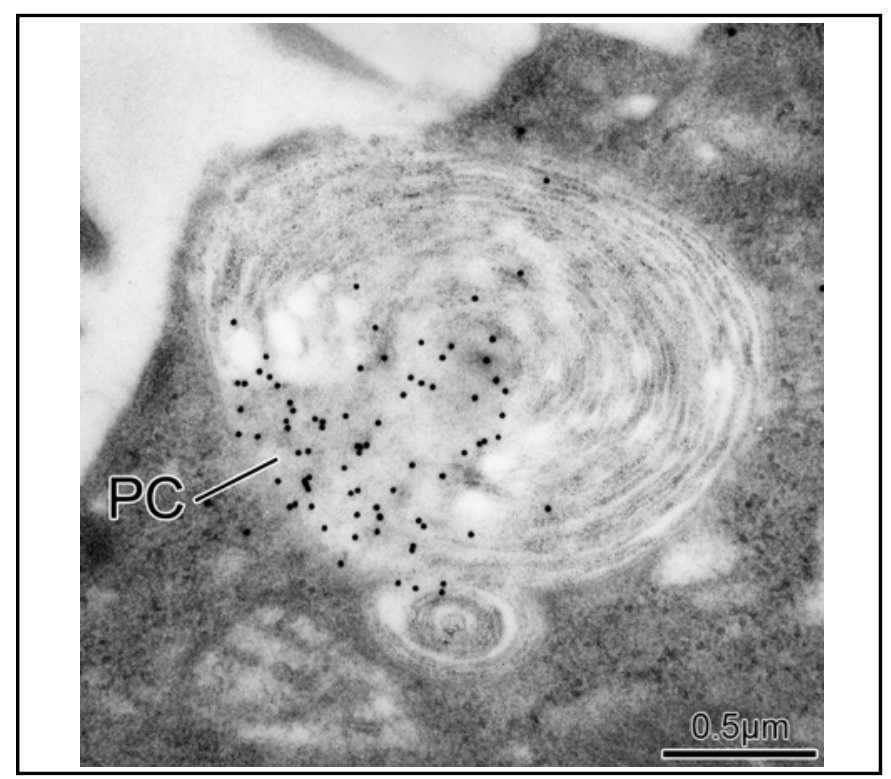

Fig. 5. Immunogold labeling for SP-B in the human lung. Fixation by airway instillation, freeze-substitution, and embedding in Lowicryl HM20 (for details of the protocol, see [22]). Within type II cells, SP-B is localized in the projection core (PC) of lamellar bodies. Reproduced with permission from [7].

are reflected by (and most likely caused by) a differential distribution of surfactant proteins, in particular SP-B [33] (Fig. 5). This finding emphasizes the importance of the combination of cryopreparation methods and colloidal gold immuno-EM for the investigation of surfactant protein localization, distribution and processing $[33,34]$.

The biogenesis of lamellar bodies and the factors regulating the size and packing of the intracellular surfactant pool are only rudimentary understood [10]. Recent data from human patients and from mouse models with genetic alterations clearly demonstrate that disordered lamellar body biogenesis results in severe lung disease. In turn, these studies help understanding normal 
lamellar body biogenesis by identifying key regulators. In principle, disorders of lamellar body biogenesis can be divided into underdevelopment (resulting in too few and/ or too small lamellar bodies) or overdevelopment (resulting in too many and/or too large lamellar bodies). Examples for underdevelopment include SP-B deficiency [35-37], ABCA3 deficiency [38-41] and TRIC-B deficiency [42]. Overdevelopment is observed e.g. in SP-D deficiency ([43, 44]; see below), ABCG1 deficiency [45] and lysosomal diseases like Hermansky-Pudlak syndrome and Chediak-Higashi syndrome [46-50]. Besides the fact that lysosomal diseases result in lamellar body alterations, lysosomal enzymes (e.g. acid phosphatase, cathepsins) and lysosomal proteins (e.g. LAMP-1, CD63/LAMP-3) as well as an acidic internal $\mathrm{pH}$ have been detected in lamellar bodies. These findings led to their classification as lysosome-related organelles [10].

Further EM-based analytical tools include energyfiltering transmission EM for high resolution analysis of elemental composition, e.g. the detection of phosphorus in lamellar bodies $[51,52]$. Besides detecting elements that are normally present in biological samples, this approach can also be applied in tracer studies [53]. A recent EM development holding great potential for surfactant analysis is electron tomography. With electron tomography, 3D stacks of "optical" slices with a z-resolution of about $2-5 \mathrm{~nm}$ are generated from tilt series recorded from thick $(200-500 \mathrm{~nm})$ sections [54-56]. This method is well suited for quantitative (stereological, see below) analysis of structures of a size comparable to, or smaller than, the thickness of a typical ultrathin (50-100 nm) section [57]. In particular, electron tomography has been demonstrated to be an ideal method for the $3 \mathrm{D}$ visualization and quantification of nanoparticles in the lung [23, 58] (Fig. 6).

Quantitative microscopy is essential in experimental morphology and pathology, including the phenotyping of genetically altered organisms. The gold standard for obtaining quantitative structural (morphometric) data at all microscopic levels is provided by state-of-the-art stereology (see [59, 60]). Stereology offers a toolkit of unbiased sampling rules (thus guaranteeing randomization of localization and spatial orientation of samples) and estimation tools based on geometric probes (sets of points, lines, planes, disectors) which allows for quantitative characterization of 3D objects on the basis of measurements made on 2D sections. By design, stereological methods make no assumptions on the size, shape, orientation or spatial distribution of the structure of interest. The objective is to estimate geometrical

Quantitative Microscopy of Surfactant

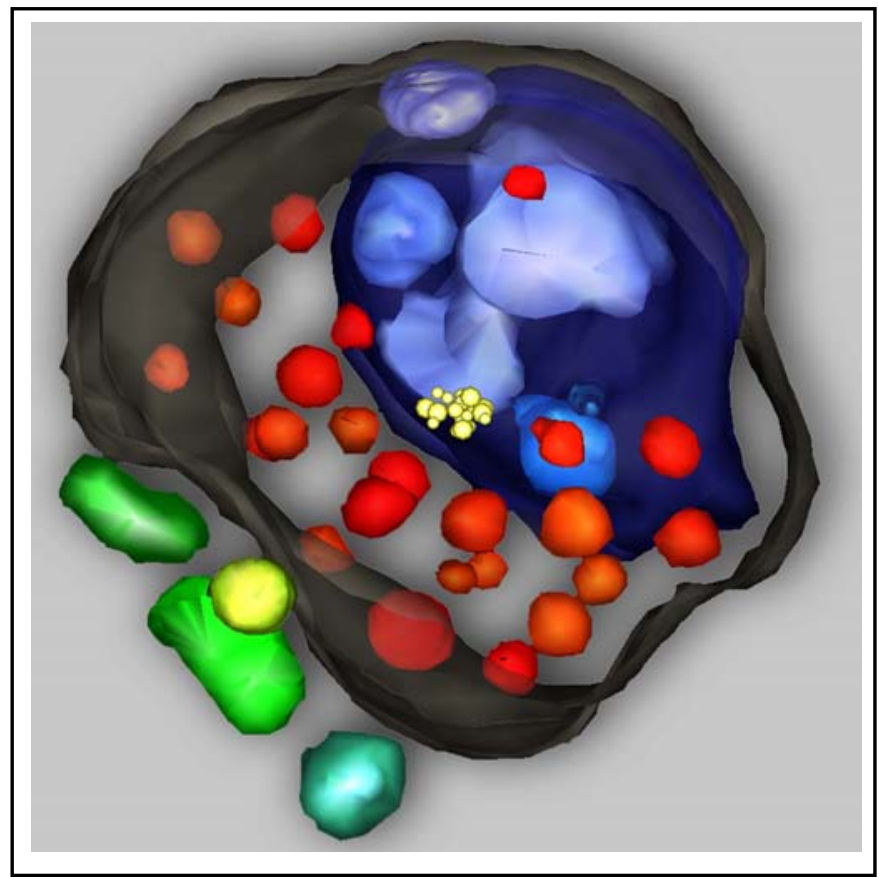

Fig. 6. Three-dimensional rendering of multivesicular body (with its limiting membrane shown in black and membranes of internal small and large vesicles in red and blue) containing 15 $\mathrm{nm}$ gold nanoparticles (clustered group of small yellow particles in the middle), based on an electron tomography dataset. Vesicles outside the multivesicular body shown in green. Reproduced with permission from [58].

parameters that characterize the composition of a structure, using a few well-distributed samples from the whole. Typical parameters that can be estimated are volume (e.g. of alveolar septal tissue), surface area (e.g. of alveolar epithelium), length (e.g. of alveolar capillaries), number (e.g. of alveolar epithelial type II cells), mean size (e.g. of lamellar bodies), and barrier thickness (e.g. of blood-air barrier). Stereological methods are accurate, efficient, simple, and transparent. Thus, they provide data that are "real" (i.e. biologically meaningful total values related to a well-defined reference space), valid, reliable, generalizable, and comparable (e.g. by formal statistics).

The combination of EM and stereology allows for qualitative and quantitative analysis of the intraalveolar as well as the intracellular surfactant pool, both in its preserved microorganization and localization within the lung. In experimental studies, lungs can be analyzed by stereology in order to detect lung pathology and alterations in the surfactant system as well as treatment effects. The Euler number is an integer-valued connectivity measure basically defining the number of elements in a network [61]. In the lung, this approach can be used to obtain unbiased and direct estimates of the number of alveoli. Using physical disectors at the light microscopic

Cell Physiol Biochem 2010;25:27-40 
Table 1. Stereological parameters for surfactant analysis. Parameters characterizing alveolar epithelial type II cells, lamellar bodies, intraalveolar surfactant and its subtypes, and surfactant proteins, are listed. Modified and extended after [26, 67].

\begin{tabular}{|c|c|c|}
\hline Parameter & Description & Method \\
\hline \multicolumn{3}{|l|}{ Type II cells } \\
\hline N(typell,lung) & total number of type II cells per lung & physical disector LM \\
\hline$v_{N}($ typell $)$ & number-weighted mean volume of type II cells & nucleator or rotator \\
\hline \multicolumn{3}{|l|}{ Lamellar bodies } \\
\hline V(lb,typell) & total volume of lamellar bodies per type II cell & point counting \\
\hline V(lb,lung) & total volume of lamellar bodies per lung & V(lb,typell)•N(typell,lung) \\
\hline $\mathrm{N}(\mathrm{lb}$,typell) & total number of lamellar bodies per type II cell & physical disector EM \\
\hline$v_{N}(l b)$ & number-weighted mean volume of lamellar bodies & V(lb,typell)/N(Ib,typell) \\
\hline$v_{\mathrm{V}}(\mathrm{lb})$ & $\begin{array}{l}\text { volume-weighted mean volume of lamellar bodies } \\
\text { size distribution of lamellar bodies }\end{array}$ & $\begin{array}{l}\text { point-sampled intercepts } \\
v_{V}=v_{N}\left(1+C V^{2}(v)\right)\end{array}$ \\
\hline \multicolumn{3}{|l|}{ Intraalveolar surfactant } \\
\hline V(alvsurf,lung) & total volume of intraalveolar surfactant per lung & point counting \\
\hline$-V_{V}(|b| / a l v s u r f)$ & -volume fraction of lamellar body-like forms & \\
\hline$-\mathrm{V}_{\mathrm{V}}(\mathrm{tm} /$ alvsurf $)$ & -volume fraction of tubular myelin & \\
\hline$-V_{\mathrm{V}}(\mathrm{mv} / \mathrm{alvsurf})$ & -volume fraction of multilamellar vesicles & \\
\hline$-V_{v}($ uv/alvsurf $)$ & -volume fraction of unilamellar vesicles & \\
\hline Surfactant proteins & surfactant protein distribution & relative labeling index \\
\hline
\end{tabular}

collagen-like domains). Both the SP-A and SP-D protein monomers consist of four subunits: an N-terminal region, a collagen-like region, a neck region, and a C-terminal carbohydrate recognition domain. Three monomers form a homotrimer, and either six homotrimers form a bouquetlike octadecamer (SP-A) or four homotrimers usually form an $\mathrm{x}$-like dodecamer (SP-D). SP-A and SP-D are multifunctional proteins involved in surfactant subtype assembly and stability as well as in immunomodulation (binding and opsonization of pathogens, interaction with immune cells, regulation of mediator production, clearance of apoptotic cells, direct antimicrobial function) [6, 1719]. SP-D and, to a somewhat lesser degree, SP-A mRNA and protein have also been localized outside the lung [7076], indicating a general role in mucosal immunity. However, there are still some controversies and inconsistent findings regarding extrapulmonary sites of SP-A and SP-D expression and localization, most likely due to possible sampling artifacts, differences in detection methods and open questions regarding the "normality" of human tissue samples obtained at autopsy or during surgery.

In alveolar epithelial type II cells, both proteins are mainly secreted by a lamellar body-independent pathway via small vesicles, thus their secretion is not directly connected with the regulated secretion of lamellar body content (i.e. lipid, SP-B and SP-C). Interestingly, intraalveolar SP-A is mainly bound to surfactant phospholipids whereas the majority of SP-D, which only binds to the minor surfactant lipid phosphatidylinositol, is not. In the alveolus, SP-A binds to the outer membranes of freshly secreted lamellar bodies, thereby initiating their transformation to tubular myelin with SP-A localized in 


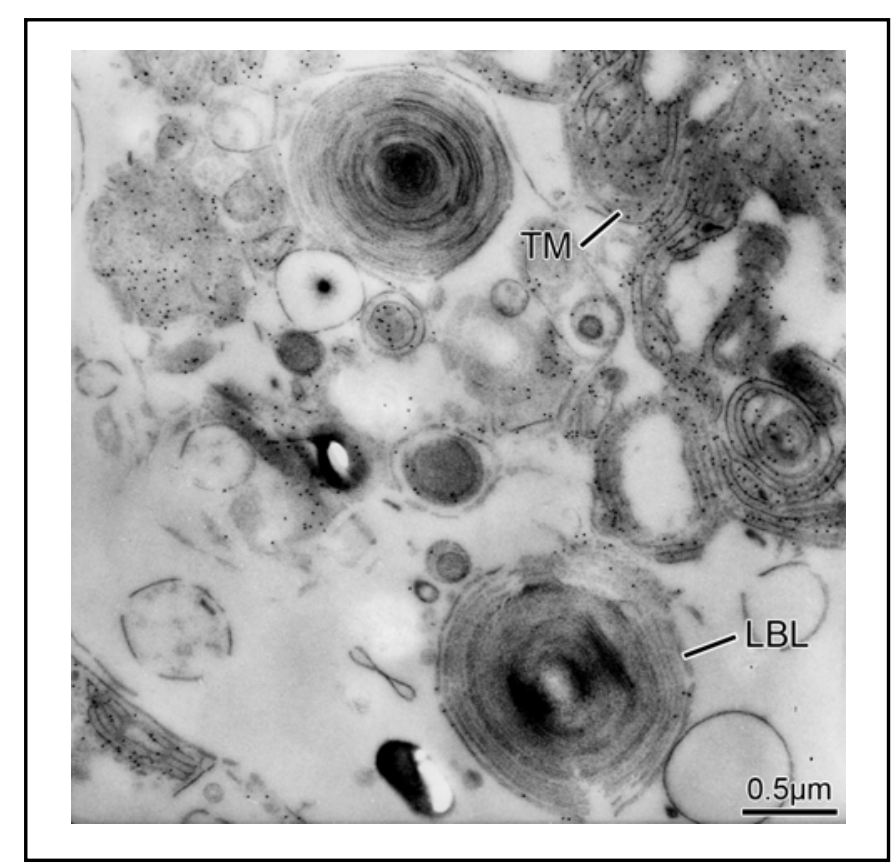

Fig. 7. Immunogold labeling for SP-A in the human lung. Within the alveolar lumen, SP-A associates with the peripheral membranes of freshly secreted lamellar body-like forms (LBL). A strong signal for SP-A is found in the lattice of tubular myelin (TM).

the corners of the lattice [34, 77] (Fig. 7). Although the functions of tubular myelin are still not understood, one might speculate that it provides a matrix for SP-A, resulting in a differential distribution of the two lung collectins in the alveolus, with one (SP-A) lipid-bound in a "spider-web" microdomain and the other (SP-D) free in the aqueous hypophase. However, findings from in vitro [78] and in vivo $[79,80]$ studies suggest that SP-D can influence intraalveolar surfactant ultrastructure, in particular by promoting conversion to and reuptake of unilamellar vesicles.

The clinical relevance of low or even absent SP-D levels has been demonstrated in several studies analyzing BAL material [81-87]. By this approach, decreased intraalveolar SP-D levels have e.g. been reported in smokers (developing COPD), in cystic fibrosis patients (correlating with the degree of inflammation), in ARDS patients (correlating with a worse clinical outcome) and in children with recurrent bronchitis (correlating with a higher incidence of pneumonias and a worse clinical outcome).

SP-D gene targeted mice exhibit a surprisingly complex phenotype [43, 88-91]. This includes accumulation of intraalveolar surfactant material (lipoproteinosis), alterations of type II cells and alveolar macrophages as well as emphysematous alterations associated with in-

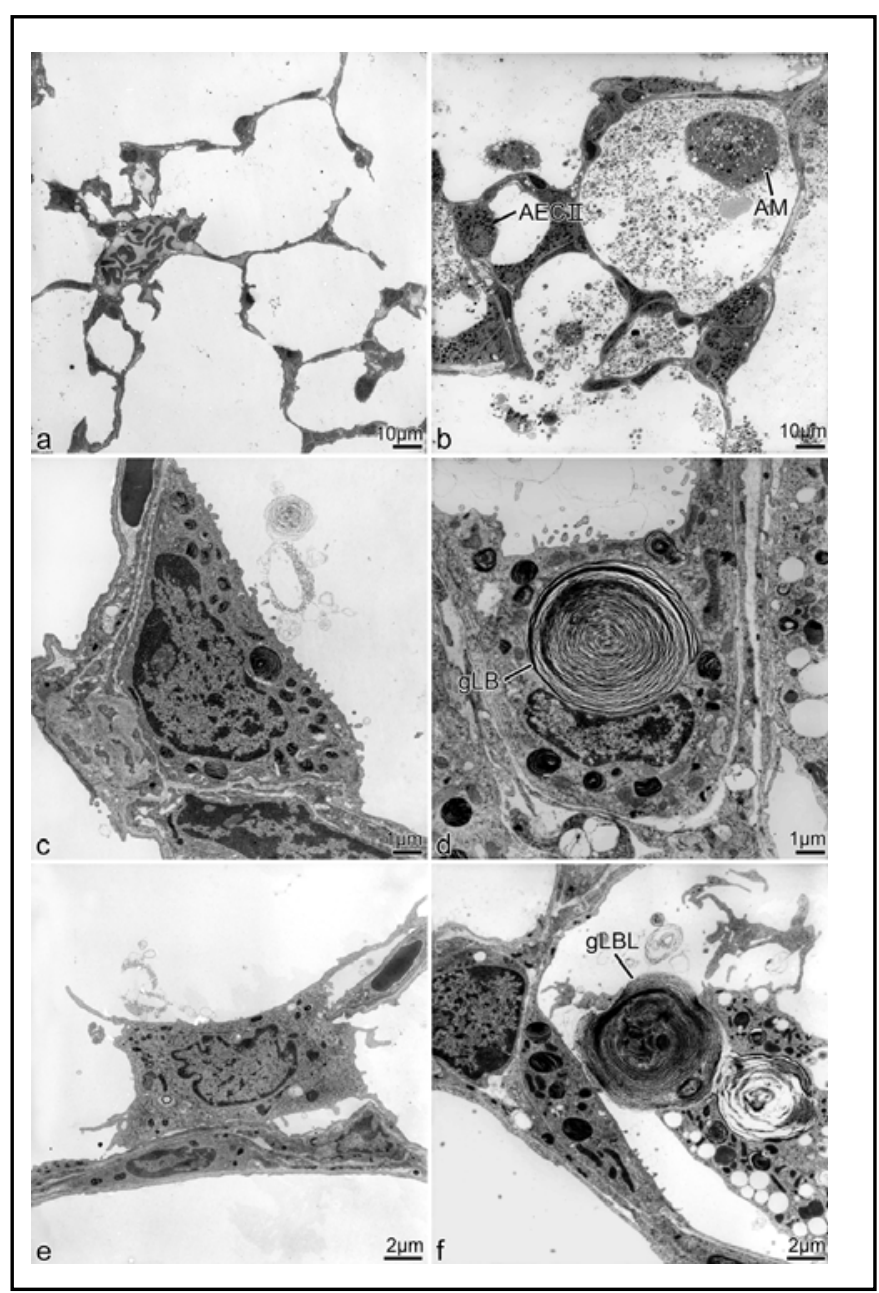

Fig. 8. Electron micrographs from lungs of wildtype (a, c, e) and lung collectin (SP-A/SP-D) double deficient mice (b, d, f) demonstrating qualitative findings for parenchymal architecture $(a, b)$, type II cells (c, d), and alveolar macrophages (e, f). Parenchymal architecture shows enlarged airspaces, thickened alveolar septae, intraalveolar surfactant accumulation, occurence of enlarged foamy alveolar macrophages (AM), and alveolar epithelial type II cell (AECII) hyperplasia in SP-A/SP$\mathrm{D}$ deficient mice (b). Type II cells of SP-A/SP-D deficient mice occasionally show giant lamellar bodies (gLB) (d). Alveolar macrophages of SP-A/SP-D deficient mice take up giant lamellar body-like forms (gLBL) from the alveolar space and are filled with surfactant material (f).

creased levels of matrix metalloproteinases and reactive oxygen and nitrogen species, suggesting an ongoing inflammatory process leading to descructive lung remodeling.

Stereological lung analysis of mice either deficient in SP-D alone [44] or in both SP-A and SP-D [92] has been performed. Mice double deficient in SP-A and SP$D$ reveal fewer and larger alveoli (consistent with emphysema-like pathology), alveolar type II cell 
hyperplasia and hypertrophy and an increased volume of lamellar bodies per type II cell and per lung, due to an increased number of lamellar bodies per cell (Fig. 8). Despite the occasional occurence of giant lamellar bodies (Fig. 8d), their mean size is unchanged, however variation in size is increased [92]. This phenotype is basically due to SP-D deficiency alone since similar alterations are seen in SP-D single deficient mice [44]. The only obvious ultrastructural alteration present in SP-A single deficient mice under unchallenged conditions is the absence of tubular myelin [93]. However, surfactant-specific functions of SP-A may become relevant under stress [94, 95] because high levels of SP-A enhance the resistance of surfactant to protein inhibition $[96,97]$ whereas SP-A deficiency results in a higher susceptibility to protein inhibition [98]. Moreover, the seemingly normal surfactant reuptake by type II cells in SP-A deficient mice is only achieved by compensatory upregulation of other (nonSP-A-mediated) endocytic mechanisms that cannot be further enhanced by secretagogues, suggesting that the system operates at its maximum capacity already at baseline conditions [99].

Granulocyte-macrophage colony-stimulating factor (GM-CSF) has been implicated as a possible mediator of the alterations seen in SP-D deficient mice. GM-CSF is an important regulator of the alveolar epithelium, surfactant homeostasis, and lung host defense [100, 101]. Alveolar epithelial type II cells and alveolar macrophages express GM-CSF and both subunits of the GM-CSF receptor. GM-CSF is required for the expression of the transcription factor PU.1, which in turn is required for most of the differentiated functions of alveolar macrophages, including the production of reactive oxygen species and the catabolism of surfactant [102]. Consequently, mice deficient in GM-CSF develop alterations reminiscent of pulmonary alveolar proteinosis [103], a disease that, in its acquired form, is caused by auto-antibodies against GM-CSF [101]. Additional deletion of GMCSF in SP-D deficient mice leads to pronounced emphysema but less pronounced alterations of type II cells and lamellar bodies, indicating that these structural abnormalities are differentially influenced by GM-CSF. These results suggest that GM-CSF, either directly or indirectly, regulates surfactant metabolism in and proliferation of type II cells, but is not required for the development of emphysema in SP-D-deficient mice [44].

One obvious attempt to correct the phenotype of SP-D deficient mice is to substitute SP-D [104]. Indeed, intranasal treatment of SP-D deficient mice with a recombinant fragment of human SP-D (rfhSP-D) con- taining a short stalk of the collagen-like domain is able to largely prevent the emphysema-like alterations as well as those of type II cells and lamellar bodies [105]. However, treatment with rfhSP-D without the short stalk of the collagen-like domain fails to do so [106], suggesting that this part of the protein, most likely by assembling three monomer fragments to form a homotrimer, is essential for its proper biological function. The therapeutic potential of rfhSP-D containing the short stalk therefore deserves further evaluation.

\section{Surfactant in lung ischemia/reperfusion injury}

In clinical lung transplantation, primary graft dysfunction (PGD) is a major problem in the early post-transplant period, leading to increased short- and long-term morbidity and mortality [107-109]. The main reason for the development of PGD is ischemia/reperfusion (I/R) injury. I/R injury manifests as acute lung injury/ARDS, a syndrome of acute and persistent lung inflammation characterized by intraalveolar edema formation, arterial hypoxia and pulmonary hypertension [110].

Alterations in surfactant composition and function are associated with $\mathrm{I} / \mathrm{R}$ associated acute lung injury in the course of experimental and clinical lung transplantation (reviewed in $[13,110]$ ). In particular, major surfactant phospholipids are decreased as are levels of SP-A and SP-B, both of which are important for formation and stabilization of surface active surfactant forms (tubular myelin). The reduced biophysical function of surfactant (increase in minimum surface tension) is reflected by an increase in the small-to-large-aggregate ratio, corresponding to a relative increase in inactive surfactant forms [111116].

These data are based on the biochemical and biophysical analysis of surfactant material obtained by BAL. However, BAL can only harvest the intraalveolar surfactant pool, and any topographical information is lost. Moreover, BAL and surfactant isolation require strictly controlled conditions to avoid errors and to make results comparable [117], especially when intraalveolar edema fluid complicates analysis [118]. An alternative approach, at least in experimental studies, is morphological surfactant analysis by EM and stereology [15]. Compared to BAL, it has the advantage of allowing for analysis of the intraalveolar and intracellular surfactant pool in situ, with preserved localization and microstructure. Due to the correlation of intraalveolar surfactant subtype structure 
Fig. 9. Perfusion-fixed rat lung samples from control (a) and ischemia/reperfusion injury (b) group. In the control group, a freshly secreted lamellar body-like form (LBL) on top of the alveolar epithelium and tubular myelin (TM) underneath the surface film (SF) are present in the alveolar lumen (a). In the ischemia/ reperfusion injury group, alveolar lumina are filled with protein-rich edema fluid (b). On one side of the alveolar septum, swellings and fragmentations of the alveolar epithelium (thin extensions of type I cells) are present, leading to partial denudations of the alveolar epithelial basal lamina (arrows). Surfactant is present mainly as unilamellar vesicles (UV). Reproduced with permission from [65].

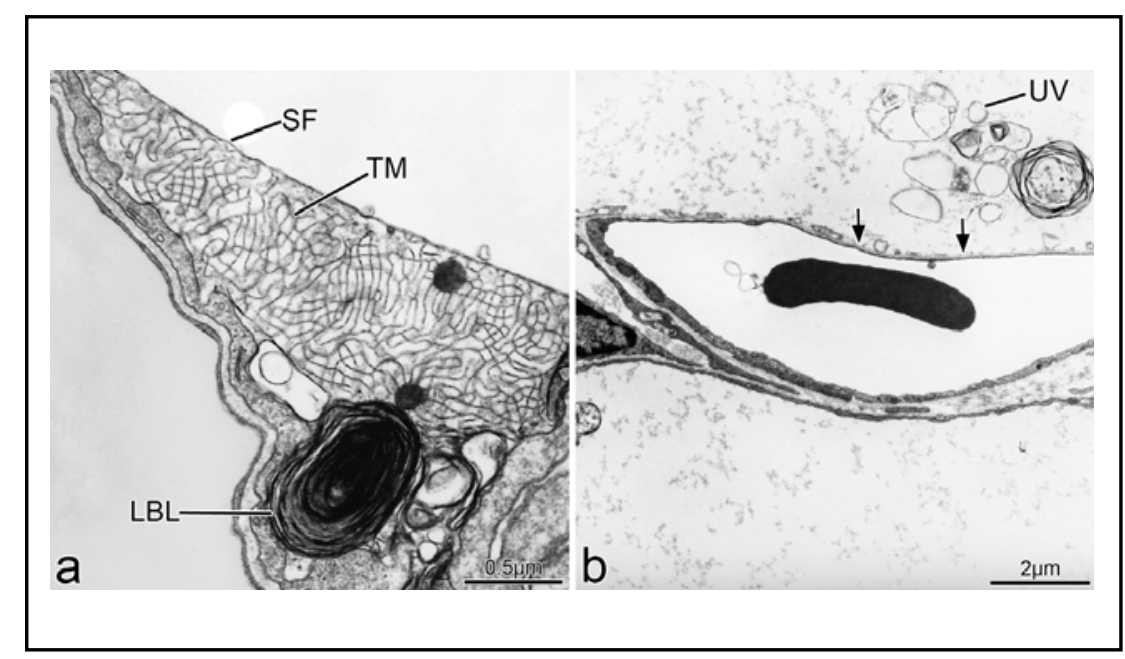

and function (Fig. 1), the small-to-large-aggregate ratio known from BAL studies can be measured in lung tissue samples as the ratio of unilamellar vesicles to tubular myelin.

In principle, $\mathrm{I} / \mathrm{R}$ injury induced surfactant alterations can occur due to damage of alveolar epithelial type II cells (thereby affecting the intracellular pool) or due to biophysical/biochemical mechanisms leading to inhibition/ inactivation of secreted surfactant (thereby affecting the intraalveolar pool) [5]. Known mechanisms in acute lung injury/ARDS include peroxidation of surfactant lipids and nitration of surfactant proteins by reactive oxygen and nitrogen species [119-122], phospholipid hydrolysis by phospholipases [123, 124], cell death of type II cells [125127], and proteolytic damage to SP-A by neutrophil elastase $[128,129]$. In addition, plasma proteins entering the alveolar space during edema formation inhibit surface film formation by competitive adsorption and inactivate surfactant components [130-133].

EM-based stereological analysis of intraalveolar surfactant in a rat lung model of $I / R$ injury reveals a decrease in active subtypes (tubular myelin) and an increase in inactive subtypes (unilamellar vesicles) (Fig. 9). These alterations correlate with postischemic lung function and they can be found in edematous as well as in non-edematous lung regions which indicates that their occurence is independent from the presence of intraalveolar edema. Thus, they are rather a cause than a mere result of edema formation $[65,66]$. An increased alveolar surface tension results in an increased pressure gradient from the capillary to the alveolar lumen, and thus in fluid fluxes across the bloodair barrier into alveoli. Components of the edema fluid, in particular plasma proteins, then further inactivate surfactant. This results in a vicious cycle of surfactant

Quantitative Microscopy of Surfactant dysfunction and edema formation.

Experimental (e.g. [134-138]) and clinical [139-142] studies demonstrate that exogenous surfactant therapy successfully supplements the disturbed endogenous surfactant system, thereby attenuating I/R injury and improving lung preservation and graft function [14]. Compared to other forms of acute lung injury/ARDS, the potential advantage of exogenous surfactant therapy of the donor in lung transplantation is that surfactant can be given prophylactically, i.e. before inhibition and inactivation manifest, so that PGD can be prevented [14].

EM-based stereological studies show that early (i.e. preischemic donor lung) treatment with an exogenous surfactant preparation prevents atelectasis formation, intraalveolar edema formation and air-blood barrier damage and stabilizes intraalveolar surfactant composition [143-145] and may therefore become a therapeutic option to optimize lung preservation during clinical lung transplantation.

Future improvements in exogenous surfactant therapy may be achieved by making exogenous surfactant preparations more resistant against inactivation or by improving their anti-inflammatory properties, e.g. by supplementing additives [146-154]. In general, surfactantprotective strategies should not only target the intraalveolar but also the intracellular pool (i.e. type II cells and their lamellar bodies). EM and stereology will be important analytical tools in experimental studies testing such therapeutic approaches.

\section{Conclusions}

It is morphology which links a genetic blueprint to the functions of an organism. In that sense, surfactant 
ultrastructure reflects genetic alterations (surfactant dysfunction mutations) as well as the functional status of the surfactant system. Compared to other microscopic techniques, EM stands out because it provides an "open view" at high resolution on cells and tissues by visualizing the complete structural context. By this, EM is also open for unexpected findings. To go beyond simple description of structure, a quantitative, i.e. stereological, approach is necessary to generate data that allow for statistically valid comparisons between groups, e.g. to detect differences between mutations or for correlation with physiological or biochemical data. Developments in cryopreparation methods (high pressure freezing, freeze substitution, ultrathin cryosectioning), in immunoelectron microscopy (colloidal gold immunolabelling), in 3D EM (electron tomography), and in quantitative microscopy (design- based stereology) now provide a basis for the analysis of the molecular topography of biological systems $[55,56$, 59, 155-158]. This armamentarium is available to characterize the lung and its surfactant system in health and disease. We can therefore indeed expect to see more if we look more closely - and more thoroughly.

\section{Acknowledgements}

The author wishes to express his sincere thanks to all coworkers and collaborators involved in our studies mentioned here. This work was supported by the German Research Foundation (DFG Oc 23/7-3 and 8-1) and the Swiss National Science Foundation (SNF 116417 and 121390).

\section{References}

ements JA: Lung surfactant: a personal perspective. Annu Rev Physiol 1997;59:1-21.

2 Hawgood S: Surfactant: composition, structure, and metabolism. In: The lung. Scientific foundations. 2nd edition. (Crystal RG, West JB, Weibel ER, Barnes PJ, eds.) Lippincott-Raven, Philadelphia 1997:557-571.

-3 Wright JR: Immunomodulatory functions of surfactant. Physiol Rev 1997;77:931962.

-4 Griese M: Pulmonary surfactant in health and human lung disease: state of the art. Eur Respir J 1999;13:1455-1476.

5 Notter RH: Lung surfactants. Basic science and clinical applications. Lung biology in health and disease. Marcel Dekker, New York 2000, vol. 149.

Wright JR: Immunoregulatory functions of surfactant proteins. Nat Rev Immunol 2005;5:58-68. Ochs M, Weibel ER: Functional design of the human lung for gas exchange. In: disorders. 4th ed.; Fishman AP, Elias JA, Fishman JA, Grippi MA, Senior RM, Pack AI (eds.): New York McGraw-Hill, 2008, pp 23-69.

Fehrenbach H: Alveolar epithelial type II cell: defender of the alveolus revisited. Respir Res 2001;2:33-46.

Schmitz G, Müller G: Structure and function of lamellar bodies, lipid-protein complexes involved in storage and secretion of cellular lipids. J Lipid Res 1991;32:1539-1570.

Weaver TE, Na CL, Stahlman M: Biogenesis of lamellar bodies, lysosomerelated organelles involved in storage and secretion of pulmonary surfactant. Sem Cell Dev Biol 2002;13:263-270.

Dietl P, Haller T: Exocytosis of lung surfactant: from the secretory vesicle to the air-liquid interface. Annu Rev Physiol 2005;67:595-621.

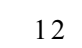

$>_{12}$ pulmonary surfactant: the role of a new serine protease. Annu Rev Physiol 1995;57:135-150.

13 Lewis JF, Novick RJ, Veldhuizen RAW: Surfactant in lung injury and lung transplantation. New York, Springer, 1997.

14 Lewis JF, Veldhuizen R: The role of exogenous surfactant in the treatment of acute lung injury. Annu Rev Physiol 2003;65:613-642.

15 Ochs M: Pulmonary surfactant preservation in experimental and clinical lung transplantation. In: Recent research developments in respiratory and critical care medicine; Pandalai SG (ed.): Trivandrum, Research Signpost, 2001, pp59-81.

6 Hawgood S, Clements J: Pulmonary surfactant and its apoproteins. J Clin Invest 1990;86:1-6.

17 Hawgood S, Poulain FR: The pulmonary collectins and surfactant metabolism. Annu Rev Physiol 2001;63:495-519. 
-18 Crouch E, Wright JR: Surfactant proteins $\mathrm{A}$ and $\mathrm{D}$ and pulmonary host defense. Annu Rev Physiol 2001;63:521-554.

19 McCormack FX, Whitsett JA: The pulmonary collectins, SP-A and SP-D, orchestrate innate immunity in the lung. J Clin Invest 2002;109:707-712.

$\checkmark 20$ Clements JA, Avery ME: Lung surfactant and neonatal respiratory distress syndrome. Am J Respir Crit Care Med 1998;157:S59-S66.

21 Weibel ER: Morphometric and stereological methods in respiratory physiology, including fixation techniques. In: Techniques in the life sciences. Techniques in respiratory physiology, part 1; Otis AB (ed.): County Clare, Elsevier, 1984, pp 1-35.

22 Fehrenbach H, Ochs M: Studying lung ultrastructure. In: Methods in pulmonary research; Uhlig S, Taylor AE (eds.): Basel, Birkhäuser, 1998, pp 429-454.

-23 Mühlfeld C, Rothen-Rutishauser B, Vanhecke D, Blank F, Gehr P, Ochs M: Visualization and quantitative analysis of nanoparticles in the respiratory system by transmission electron microscopy. Part Fibre Toxicol 2007;4:11:1-17.

24 Crang RFE, Klomparens KL: Artifacts in biological electron microscopy. New York, Plenum Press, 1988.

-25 Studer D, Humbel B, Chiquet M: Electron microscopy of high pressure frozen samples: bridging the gap between cellular ultrastructure and atomic resolution. Histochem Cell Biol 2008;130:877-889.

26 Ochs M: A brief update on lung stereology. J Microsc 2006;222:188-200.

$\checkmark 27$ Kikkawa Y, Spitzer R: Inclusion bodies of type II alveolar cells: species differences and morphogenesis. Anat Rec 1969; 163:525-542.

-28 Pattle RE, Gandy G, Schock C, Creasey JM: Lung inclusion bodies: different ultrastructure in simian and non-simian mammals. Experientia 1974;30:797798.

29 Stratton CJ: Morphology of surfactant producing cells and of the alveolar lining layer. In: Pulmonary surfactant (Robertson B, Van Golde LMG, Batenburg JJ, eds.) Elsevier, Amsterdam 1984:67118 .

-30 Fehrenbach H, Schmiedl A, Wahlers T, Hirt SW, Brasch F, Riemann D, Richter $\mathrm{J}$ : Morphometric characterisation of the fine structure of human type II pneumocytes. Anat Rec 1995;243:49-62.

-31 Al-Amoudi A, Chang JJ, Leforestier A, McDowall A, Salamin LM, Norlen LPO, Richter K, Blanc NS, Studer D, Dubochet J: Cryo-electron microscopy of vitreous sections. EMBO J 2004;23:3583-3588

32 Perez-Gil J: Structure of pulmonary surfactant membranes and films: the role of proteins and lipid-protein interactions. Biochim Biophys Acta 2008;1778:1676-1695.
Brasch F, Johnen G, Winn-Brasch A, Guttentag SH, Schmiedl A, Kapp N, Suzuki Y, Müller KM, Richter J, Hawgood S, Ochs M: Surfactant protein B in type II pneumocytes and intra-alveolar surfactant forms of human lungs. Am J Respir Cell Mol Biol 2004;30:449-458. Ochs M, Johnen G, Müller KM, Wahlers T, Hawgood S, Richter J, Brasch F: Intracellular and intraalveolar localization of surfactant protein A (SPA) in the human lung. Am J Respir Cell Mol Biol 2002;26:91-98.

Nogee LM, DeMello DE, Dehner LP, 46 Colten HR: Deficiency of pulmonary surfactant protein $B$ in congenital alveolar proteinosis. N Engl J Med 1993;328:406-410.

DeMello DE, Heyman S, Phelps DS, Hamvas A, Nogee L, Cole S, Colten HR: Ultrastructure of lung in surfactant protein B deficiency. Am J Respir Cell Mol Biol 1994;11:230-239.

Clark JC, Wert SE, Bachurski CJ, Stahlman MT, Stripp BR, Weaver TE, Whitsett JA: Targeted disruption of the surfactant protein B gene disrupts surfactant homeostasis, causing respiratory failure in newborn mice. Proc Natl Acad Sci USA 1995;92:7794-7798. Shulenin S, Nogee LM, Annilo T, Wert SE, Whitsett JA, Dean M: ABCA3 gene mutations in newborns with fatal surfactant deficiency. N Engl J Med 2004;350:1296-1303.

Fitzgerald ML, Xavier R, Haley KJ, Welti R, Goss JL, Brown CE, Zhuang DZ, Bell SA, Lu N, McKee M, Seed B, Freeman MW: ABCA3 inactivation in mice causes respiratory failure, loss of pulmonary surfactant, and depletion of lung phosphatidylglycerol. J Lipid Res 2007;48:621-632.

Ban N, Matsumura Y, Sakai H, Takanezawa Y, Sasaki M, Arai H, Inagaki $\mathrm{N}$ : ABCA3 as a lipid transporter in pulmonary surfactant biogenesis. J Biol Chem 2007;282:9628-9634.

Hammel M, Michel G, Hoefer C, Klaften M, Müller-Höcker J, de Angelis $\mathrm{MH}$, Holzinger A: Targeted inactivation of the murine Abca3 gene leads to respiratory failure in newborns with defective lamellar bodies. Biochem Biophys Res Comm 2007;359:947-951.

Yamazaki D, Komazaki S, Nakanishi H, Mishima A, Nishi M, Yazawa M, Yamazaki T, Taguchi R, Takeshima H: Essential role of the TRIC-B channel in $\mathrm{Ca} 2+$ handling of alveolar epithelial cells and in perinatal lung maturation. Development 2009;136:2355-2361.

43 Botas C, Poulain F, Akiyama J, Brown C, Allen L, Goerke J, Clements J, Carlson E, Gillespie AM, Epstein C, Hawgood S: Altered surfactant homeostasis and alveolar type II cell morphology in mice lacking surfactant protein D. Proc Nat Acad Sci USA 1998;95:11869-11874.
Ochs M, Knudsen L, Allen L, Stumbaugh A, Levitt S, Nyengaard JR, Hawgood S: GM-CSF mediates alveolar epithelial type II changes, but not emphysema-like pathology, in SP-D deficient mice. Am J Physiol Lung Cell Mol Physiol 2004;287:L1333-L1341.

45 Baldán A, Tarr P, Vales CS, Frank J, Shimotake TK, Hawgood S, Edwards PA: Deletion of the transmembrane transporter ABCG1 results in progressive pulmonary lipidosis. J Biol Chem 2006;281:29401-29410.

Chi EY, Lagunoff D, Koehler JK: Abnormally large lamellar bodies in type II pneumocytes in Chediak-Higashi syndrome in beige mice. Lab Invest 1976;34:166-173.

Nakatani Y, Nakamura N, Sano J, Inayama Y, Kawano N, Yamanaka S, Miyagi Y, Nagashima Y, Ohbayashi C, Mizushima M, Manabe T, Kuroda M, Yokoi T, Matsubara O: Interstitial pneumonia in Hermansky-Pudlak syndrome: significance of florid foamy swelling/degeneration (giant lamellar body degeneration) of type-2 pneumocytes. Virchows Arch 2000;437:304-313.

48 Lyerla TA, Rusiniak ME, Borchers M, Jahreis G, Tan J, Ohtake P, Novak EK, Swank RT: Aberrant lung structure, composition, and function in a murine model of Hermansky-Pudlak syndrome. Am J Physiol Lung Cell Mol Physiol 2003;285:L643-L653.

49 Guttentag SH, Akhtar A, Tao JQ, Atochina E, Rusiniak ME, Swank RT, Bates SR: Defective surfactant secretion in a mouse model of Hermansky-Pudlak syndrome. Am J Respir Cell Mol Biol 2005;33:14-21

50 Tang X, Yamanaka S, Miyagi Y, Nagashima Y, Nakatani Y: Lung pathology of pale ear mouse (model of Hermansky-Pudlak syndrome 1) and beige mouse (model of Chediak-Higashi syndrome): severity of giant lamellar body degeneration of type II pneumocytes correlates with interstitial inflammation. Pathol Int 2005;55:137143

51 Ochs M, Fehrenbach H, Richter J: Electron spectroscopic imaging (ESI) and electron energy loss spectroscopy (EELS) of multilamellar bodies and multilamellar body-like structures in tannic acid-treated alveolar septal cells. J Histochem Cytochem 1994;42:805809.

$\$ 52$ Ochs M, Fehrenbach H, Richter J: Ultrastructure of canine type II pneumocytes during hypothermic ischemia of the lung - a study by means of conventional and energy filtering transmission electron microscopy and stereology. Anat Rec 2001;263:118-126. 
53 Fehrenbach H, Ochs M, Richter J: Energy-filtering TEM in the finestructural study of the mammalian lung. Microsc Anal 1995;37:11-14.

$>54$ Baumeister W, Grimm R, Walz J: Electron tomography of molecules and cells. Trends Cell Biol 1999;9:81-85.

55 Bonetta L: Zooming in on electron tomography. Nat Methods 2005;2:139145 .

$\$ 56$ Lucic V, Leis A, Baumeister W: Cryoelectron tomography of cells: connecting structure and function. Histochem Cell Biol 2008;130:185-196.

57 Vanhecke D, Studer D, Ochs M Stereology meets electron tomography: towards quantitative $3 \mathrm{D}$ electron microscopy. J Struct Biol 2007;159:443450.

58 Mayhew TM, Mühlfeld C, Vanhecke D, Ochs M: A review of recent methods for efficiently quantifying immunogold and other nanoparticles using TEM sections through cells, tissues and organs. Ann Anat 2009;191:153-170.

59 Howard CV, Reed MG: Unbiased 73 stereology. Three-dimensional measurement in microscopy. 2nd edition: Oxford, Bios, 2005.

60 Baddeley A, Vedel Jensen EB: Stereology for statisticians. Chapman \& Hall, Boca $>74$ Raton 2005.

61 Gundersen HJG, Boyce RW, Nyengaard JR, Odgaard A: The conneulor: unbiased estimation of connectivity using physical disectors under projection. Bone $>75$ 1993; 14:217-222.

62 Ochs M, Nyengaard JR, Jung A, Knudsen L, Voigt M, Wahlers T, Richter J, Gundersen HJG: The number of alveoli in the human lung. Am J Respir Crit Care Med 2004;169:120-124.

63 Hyde DM, Tyler NK, Putney LF, Singh P, Gundersen HJG: Total number and mean size of alveoli in mammalian lung estimated using fractionator sampling and unbiased estimates of the Euler characteristic of alveolar openings. Anat Rec 2004;277:216-226.

64 Knust J, Ochs M, Gundersen HJG, Nyengaard JR: Stereological estimates of alveolar number and size and capillary length and surface area in mice lungs. Anat Rec 2009;292:113-122.

65 Ochs M, Nenadic I, Fehrenbach A, Albes JM, Wahlers T, Richter J, Fehrenbach H: Ultrastructural alterations in intraalveolar surfactant subtypes after experimental ischemia and reperfusion. Am J Respir Crit Care Med 1999;160:718-724.

-66 Ochs M, Fehrenbach H, Nenadic I, Bando T, Fehrenbach A, Schepelmann D, Albes JM, Wahlers T, Richter J: Preservation of intraalveolar surfactant in a rat lung ischaemia/reperfusion injury model. Eur Respir J 2000;15:526-531.

67 Ochs M: Stereological analysis of acute lung injury. Eur Respir Rev 2006;15:115121.
Weibel ER, Hsia CCW, Ochs M: How much is there really? Why stereology is essential in lung morphometry. J Appl Physiol 2007;102:459-467.

69 Hsia CCW, Hyde DM, Ochs M, Weibel ER: Standards for quantitative assessment of lung structure. An official research policy statement of the ATS/ERS. Am J Respir Crit Care Med 2009; in press.

70 Madsen J, Kliem A, Tornoe I, Skjodt K, Koch C, Holmskov U: Localization of lung surfactant protein D on mucosal surfaces in human tissues. J Immunol 2000;164:5866-5870.

Stahlman MT, Gray ME, Hull WM, Whitsett JA: Immunolocalization of surfactant protein D (SP-D) in human fetal, newborn, and adult tissues. J Histochem Cytochem 2002;50:651660 .

72 Akiyama J, Hoffman A, Brown C, Allen L, Edmondson J, Poulain F, Hawgood S: Tissue distribution of surfactant proteins $\mathrm{A}$ and $\mathrm{D}$ in the mouse. $\mathrm{J}$ Histochem Cytochem 2002;50:993-996.

Madsen J, Tornoe I, Nielsen O, Koch C, Steinhilber W, Holmskov U: Expression and localization of lung surfactant protein A in human tissues. Am J Respir Cell Mol Biol 2003;29:591-597.

Woodworth BA, Lathers D, Neal JG, Skinner M, Richardson M, Young MR, Schlosser RJ: Immunolocalization of surfactant protein A and D in sinonasal mucosa. Am J Rhinol 2006;20:461-465. Mo YK, Kankavi O, Masci PP, Mellick GD, Whitehouse MW, Boyle GM, Parsons PG, Roberts MS, Cross SE: Surfactant protein expression in human skin: evidence and implications. J Invest Dermatol 2007;127:381-386.

Bräuer L, Kindler C, Jäger K, Sel S, Nölle B, Pleyer U, Ochs M, Paulsen FP: Detection of surfactant proteins A and D in human tear fluid and the human lacrimal system. Invest Ophthalmol Vis Sci 2007;48:3945-3953.

77 Voorhout WF, Veenendaal T, Haagsman HP, Verkleij AJ, Van Golde LMG, Geuze HJ: Surfactant protein A is localized at the corners of the pulmonary tubular myelin lattice. J Histochem Cytochem 1991;39:1331-1336.

78 Poulain FR, Akiyama J, Allen L, Brown $>88$ C, Chang R, Goerke J, Dobbs L, Hawgood S: Ultrastructure of phospholipid mixtures reconstituted with surfactant proteins B and D. Am J Respir Cell Mol Biol 1999;20:1049-1058

79 Ikegami M, Na CL, Korfhagen TR, Whitsett JA: Surfactant protein D influences surfactant ultrastructure and uptake by alveolar type II cells. Am J Physiol Lung Cell Mol Physiol 2005;288:L552-L561.
Ikegami M, Grant S, Korfhagen T, Scheule RK, Whitsett JA: Surfactant protein-D regulates the postnatal maturation of pulmonary surfactant lipid pool sizes. J Appl Physiol 2009;106:1545-1552.

Honda Y, Takahashi H, Kuroki Y, Akino $\mathrm{T}$, Abe $\mathrm{S}$ : Decreased contents of surfactant proteins A and D in BAL fluids of healthy smokers. Chest 1996;109:1006-1009.

82 Postle AD, Mander A, Reid KBM, Wang JY, Wright SM, Moustaki M, Warner JO: Deficient hydrophilic lung surfactant proteins $\mathrm{A}$ and $\mathrm{D}$ with normal surfactant phospholipid molecular species in cystic fibrosis. Am J Respir Cell Mol Biol 1999;20:90-98.

Greene KE, Wright JR, Steinberg KP, Ruzinski JT, Caldwell E, Wong WB, Hull W, Whitsett JA, Akino T, Kuroki Y, Nagae H, Hudson LD, Martin TR: Serial changes in surfactant-associated proteins in lung and serum before and after onset of ARDS. Am J Respir Crit Care Med 1999;160:1843-1850

Noah TL, Murphy PC, Alink JJ, Leigh MW, Hull WM, Stahlman MT, Whitsett JA: Bronchoalveolar lavage fluid surfactant protein-A and surfactant protein-D are inversely related to inflammation in early cystic fibrosis. Am J Respir Crit Care Med 2003;168:685691.

Griese M, Essl R, Schmidt R, Rietschel E, Ratjen F, Ballmann M, Paul K: Pulmonary surfactant, lung function, and endobronchial inflammation in cystic fibrosis. Am J Respir Crit Care Med 2004;170:1000-1005.

86 Griese M, Steinhecker M, Schumacher S, Braun A, Lohse P, Heinrich S: Children with absent surfactant protein D in bronchoalveolar lavage have more frequently pneumonia. Pediatr Allergy Immunol 2008;19:639-647.

87 Sims MW, Tal-Singer RM, Kierstein S, Musani AI, Beers MF, Panettieri RA, Haczku A: Chronic obstructive pulmonary disease and inhaled steroids alter surfactant protein D (SP-D) levels: a cross-sectional study. Respir Res 2008;9:13:1-9

Korfhagen TR, Sheftelyevich V, Burhans MS, Bruno MD, Ross GF, Wert SE, Stahlman MT, Jobe AH, Ikegami M, Whitsett JA, Fisher JH: Surfactant protein-D regulates surfactant phospholipid homeostasis in vivo. J Biol Chem 1998;273:28438-28443.

Ikegami M, Whitsett JA, Jobe A, Ross G, Fisher J, Korfhagen T: Surfactant metabolism in SP-D gene-targeted mice. Am J Physiol Lung Cell Mol Physiol 2000;279:L468-L476. 
-90 Wert SE, Yoshida M, LeVine AM, Ikegami M, Jones T, Ross GF, Fisher JH, Korfhagen TR, Whitsett JA: Increased metalloproteinase activity, oxidant production, and emphysema in surfactant protein D gene-inactivated mice. Proc Natl Acad Sci USA 2000;97:5972-5977.

$\checkmark 91$ Atochina EN, Beers MF, Hawgood S, Poulain F, Davis C, Fusaro TT, Gow AJ: Surfactant protein-D, a mediator of innate lung immunity, alters the products of NO metabolism. Am J Respir Cell Mol Biol 2004;30:271-279.

$\$ 92$ Jung A, Allen L, Nyengaard JR, Gundersen HJG, Richter J, Hawgood S, Ochs M: Design-based stereological analysis of the lung parenchymal architecture and alveolar type II cells in surfactant protein $\mathrm{A}$ and $\mathrm{D}$ double deficient mice. Anat Rec 2005;286:885-890.

$\$ 93$ Korfhagen TR, Bruno MD, Ross GF, Huelsman KM, Ikegami M, Jobe AH, Wert SE, Stripp BR, Morris RE, Glasser SW, Bachurski CJ, Iwamoto HS, Whitsett JA: Altered surfactant function and structure in SP-A gene targeted mice. Proc Natl Acad Sci USA 1996;93:9594-9599.

$\$ 94$ McCormack FX: Structure, processing and properties of surfactant protein A. Biochim Biophys Acta 1998;1408:109131 .

$\$ 95$ Mason RJ, Greene K, Voelker DR: Surfactant protein A and surfactant protein D in health and disease. Am J Physiol Lung Cell Mol Physiol 1998;275:L1-L13.

$\$ 96$ Yukitake K, Brown CL, Schlueter MA, Clements JA, Hawgood S: Surfactant apoprotein A modifies the inhibitory effect of plasma proteins on surfactant activity in vivo. Pediatr Res 1995;37:2125.

$\$ 97$ Elhalwagi BM, Zhang M, Ikegami M, Iwamoto HS, Morris RE, Miller ML, Dienger K, McCormack FX: Normal surfactant pool sizes and inhibitionresistant surfactant from mice that overexpress surfactant protein A. Am J Respir Cell Mol Biol 1999;21:380-387.

$\$ 98$ Ikegami M, Korfhagen TR, Whitsett JA, Bruno MD, Wert SE, Wada K, Jobe AH: Characteristics of surfactant from SPA-deficient mice. Am J Physiol Lung Cell Mol Physiol 1998;275:L247-L254.

$\checkmark 99$ Bates SR, Dodia C, Tao JQ, Fisher AB: Surfactant protein-A plays an important role in lung surfactant clearance: evidence using the surfactant protein-A genetargeted mouse. Am J Physiol Lung Cell Mol Physiol 2008;294:L325-L333.

$\checkmark 100$ Trapnell BC, Whitsett JA: GM-CSF regulates pulmonary surfactant homeostasis and alveolar macrophagemediated innate host defense. Annu Rev Physiol 2002;64:775-802.

101 Trapnell BC, Whitsett JA, Nakata K: Pulmonary alveolar proteinosis. N Engl J Med 2003;349:2527-2539.
102 Shibata Y, Berclaz PY, Chroneos ZC, Yoshida M, Whitsett JA, Trapnell BC: GM-CSF regulates alveolar macrophage differentiation and innate immunity in the lung through PU.1. Immunity 2001;15:557-567.

103 Dranoff G, Crawford AD, Sadelain M, Ream B, Rashid A, Bronson RT, Dickersin GR, Bachurski CJ, Mark EL, Whitsett JA, Mulligan RC: Involvement of granulocate-macrophage colonystimulating factor in pulmonary homeostasis. Science 1994;264:713-716.

104 Strong P, Reid KBM, Clark HW: Intranasal delivery of a truncated recombinant human SP-D is effective at down-regulating allergic hypersensitivity in mice sensitized to allergens of Aspergillus fumigatus. Clin Exp Immunol 2002;130:19-24

105 Knudsen L, Ochs M, Mackay RM, Townsend P, Deb R, Mühlfeld C, Richter J, Gilbert F, Hawgood S, Reid K, Clark H: Truncated recombinant human SP-D attenuates emphysema and type II cell changes in SP-D deficient mice. Respir Res 2007;8:70:1-12.

106 Knudsen L, Wucherpfennig K, Mackay RM, Townsend P, Mühlfeld C, Richter J, Hawgood S, Reid K, Clark H, Ochs M: A recombinant fragment of human surfactant protein D lacking the short collagen-like stalk fails to correct morphological alterations in lungs of SP$D$ deficient mice. Anat Rec 2009;292:183-189.

107 Christie JD, Carby M, Bag R, Corris P, Hertz M, Weill D: Report of the ISHLT working group on primary lung graft dysfunction part II: definition. A consensus statement of the International Society for Heart and Lung Transplantation. J Heart Lung Transplant 2005;24:1454-1459.

108 Christie JD, Kotloff RM, Ahya VN, Tino G, Pochettino A, Gaughan C, DeMissie E, Kimmel SE: The effect of primary graft dysfunction on survival after lung transplantation. Am J Respir Crit Care Med 2005;71:1312-1316.

109 Daud SA, Yusen RD, Meyers BF, Chakinala MM, Walter MJ, Aloush AA, Patterson GA, Trulock EP, Hachem RR: Impact of immediate primary lung allograft dysfunction on bronchiolitis obliterans syndrome. Am J Respir Crit Care Med 2007;175:507-513.

110 DePerrot M, Liu M, Waddell TK, Keshavjee S: Ischemia-reperfusioninduced lung injury. Am J Respir Crit Care Med 2003;167:490-511.

111 Veldhuizen RAW, Lee J, Sandler D, Hull W, Whitsett JA, Lewis J, Possmayer F, Novick RJ: Alterations in pulmonary surfactant composition and activity after experimental lung transplantation. Am Rev Respir Dis 1993;148:208-215.
112 Erasmus ME, Petersen AH, Bambang Oetomo S, Prop J: The function of surfactant is impaired during the reimplantation response in rat lung transplants. J Heart Lung Transplant 1994;13:791-802.

113 Casals C, Varela A, Ruano MLF, Valino F, Perez-Gil J, Torre N, Jorge E, Tendillo F, Castillo-Olivares JL: Increase of $\mathrm{C}$ reactive protein and decrease of surfactant protein A in surfactant after lung transplantation. Am J Respir Crit Care Med 1998;157:43-49.

114 Hohlfeld JM, Tiryaki E, Hamm H, Hoymann HG, Krug N, Haverich A, Fabel $\mathrm{H}$ : Pulmonary surfactant activity is impaired in lung transplant recipients. Am J Respir Crit Care Med 1998;158:706-712

$\$ 115$ Maitra G, Inchley K, Novick RJ, Veldhuizen RAW, Lewis JF, Possmayer F: Acute lung injury and lung transplantation influence in vitro subtype conversion of pulmonary surfactant. Am J Physiol Lung Cell Mol Physiol 2002;282:L67-L74.

116 Warnecke G, Strüber M, Hohlfeld JM, Niedermeyer J, Sommer SP, Haverich A: Pulmonary preservation with Bretschneider's HTK and Celsior solution in minipigs. Eur J Cardiothorac Surg 2002;21:1073-1079.

117 Haslam PL, Postle AD, Raymondos K, Baker CS: Measurement of pulmonary surfactant components and function in bronchoalveolar lavage fluid. Eur Respir Rev 1999;9:43-69.

118 Tiroke AH, Bewig B, Haverich A: Bronchoalveolar lavage in lung transplantation. State of the art. Clin Transplant 1999;13:131-157.

119 Haddad IY, Ischiropoulos H, Holm BA, Beckman JS, Baker JR, Matalon S: Mechanisms of peroxynitrite-induced injury to pulmonary surfactants. Am J Physiol Lung Cell Mol Physiol 1993;265:L555-L564.

120 Putman E, Van Golde LMG, Haagsman HP: Toxic oxidant species and their impact on the pulmonary surfactant system. Lung 1997;175:75-103.

121 Andersson S, Kheiter A, Merritt TA: Oxidative inactivation of surfactants. Lung 1999;177:179-189.

122 Zhu S, Ware LB, Geiser T, Matthay MA, Matalon S: Increased levels of nitrate and surfactant protein A nitration in the pulmonary edema fluid of patients with acute lung injury. Am J Respir Crit Care Med 2001;163:166-172.

$\checkmark 123$ Hurley BP, McCormick BA: Multiple roles of phospholipase A2 during lung infection and inflammation. Infect Immunity 2008;76:2259-2272.

124 Kitsiouli E, Nakos G, Lekka ME: Phospholipase A2 subclasses in acute respiratory distress syndrome. Biochim Biophys Acta 2009;1792:941-953. 
125 Fischer S, Cassivi SD, Xavier AM, Cardella JA, Cutz E, Edwards V, Liu M, Keshavjee S: Cell death in human lung transplantation: apoptosis induction in human lungs during ischemia and after transplantation. Ann Surg 2000;231:424-431.

126 Fischer S, Maclean AA, Liu M, Cardella JA, Slutsky AS, Suga M, Moreira JFM, Keshavjee S: Dynamic changes in apoptotic and necrotic cell death correlate with severity of ischemiareperfusion injury in lung transplantation. Am J Respir Crit Care Med 2000;162:1932-1939.

127 Stammberger U, Gaspert A, Hillinger S, Vogt P, Odermatt B, Weder W, Schmid RA: Apoptosis induced by ischemia and reperfusion in experimental lung transplantation. Ann Thorac Surg 2000;69:1532-1536.

128 Pison U, Tam EK, Caughey GH, Hawgood S: Proteolytic inactivation of dog lung surfactant-associated proteins by neutrophil elastase. Biochim Biophys Acta 1989;992:251-257.

129 Baker CS, Evans TW, Randle BJ, Haslam PL: Damage to surfactant-specific protein in acute respiratory distress syndrome. Lancet 1999;353:12321237.

130 Seeger W, Stöhr G, Wolf HRD, Neuhoff $\mathrm{H}$ : Alteration of surfactant function due to protein leakage: special interaction with fibrin monomer. J Appl Physiol 1985;58:326-338.

131 Nitta K, Kobayashi T: Impairment of surfactant activity and ventilation by proteins in lung edema fluid. Respir Physiol 1994;95:43-51.

132 Ueda T, Ikegami M, Jobe A: Surfactant subtypes. In vitro conversion, in vivo function, and effects of serum proteins. Am J Respir Crit Care Med 1994;149:1254-1259.

-133 Fernsler JG, Zasadzinski JA: Competitive adsorption: a physical model for lung surfactant inactivation. Langmuir 2009;25:8131-8143.

134 Novick RJ, MacDonald J, Veldhuizen RA, Wan F, Duplan J, Denning L Possmayer F, Gilpin AA, Yao LJ, Bjarneson D, Lewis JF: Evaluation of surfactant treatment strategies after prolonged graft storage in lung transplantation. Am J Respir Crit Care Med 1996;154:98-104.

$\$ 135$ Erasmus ME, Petersen AH, Hofstede G, Haagsman HP, Bambang Oetomo S, Prop $\mathrm{J}$ : Surfactant treatment before reperfusion improves the immediate function of lung transplants in rats. Am J Respir Crit Care Med 1996;153:665-670.

136 Hohlfeld JM, Strüber M, Ahlf K, Hoeper MM, Fraund S, Krug N, Warnecke G, Harringer W, Haverich A, Fabel H: Exogenous surfactant improves survival and surfactant function in ischaemiareperfusion injury in minipigs. Eur Respir J 1999;13:1037-1043.
137 Friedrich I, Börgermann J, Splittgerber FH, Brinkmann M, Reidemeister JC, Silber RE, Seeger W, Schmidt R, Günther A: Bronchoscopic surfactant administration preserves gas exchange and pulmonary compliance after single lung transplantation. J Thorac Cardiovasc Surg 2004;127:335-343.

138 Van der Kaaij NP, Haitsma JJ, Kluin J, Lambrecht BN, Lachmann B, de Bruin RW, Bogers AJ: Surfactant pretreatment ameliorates ischemia-reperfusion injury of the lung. Eur J Cardiothorac Surg 2005;27:774-782

139 Strüber M, Hirt SW, Cremer J, Harringer W, Haverich A: Surfactant replacement in reperfusion injury after clinical lung transplantation. Intensive Care Med 1999;25:862-864

140 Strüber M, Fischer S, Niedermeyer J, Warnecke G, Gohrbandt B, Görler A, Simon AR, Haverich A, Hohlfeld JM: Effects of exogenous surfactant instillation in clinical lung transplantation: a prospective, randomized trial. J Thorac Cardiovasc Surg 2007;133:1620-1625.

141 Kermeen FD, McNeil KD, Fraser JF, McCarthy J, Ziegenfuss MD, Mullany D, Dunning J, Hopkins PM: Resolution of severe ischemia-reperfusion injury postlung transplantation after administration of endobronchial surfactant. J Heart Lung Transplant 2007;26:850-856.

142 Amital A, Shitrit D, Raviv Y, Saute M, Medalion B, Bakal I, Kramer MR: The use of surfactant in lung transplantation. Transplantation 2008;86:1554-1559.

143 Dreyer N, Mühlfeld C, Fehrenbach A, Pech T, von Berg S, Nagib R, Richter J, Wittwer T, Wahlers T, Ochs M: Exogenous surfactant application in a rat lung ischemia reperfusion injury model: effects on edema formation and alveolar type II cells. Respir Res 2008;9:5:1-10.

144 Mühlfeld C, Schaefer IM, Becker L, Bussinger C, Vollroth M, Bosch A, Nagib R, Madershahian N, Richter J, Wahlers T, Wittwer T, Ochs M: Pre-ischaemic exogenous surfactant reduces pulmonary injury in rat ischaemia/reperfusion. Eur Respir J 2009;33:625-633.

145 Mühlfeld C, Becker L, Bussinger C, Vollroth M, Nagib R, Schaefer IM, Knudsen L, Richter J, Madershahian N, Wahlers T, Wittwer T, Ochs M: Exogenous surfactant in ischemia/ reperfusion: effects on endogenous surfactant pools. J Heart Lung Transplant 2009; in press.

146 Taeusch HW, Lu KW, Goerke J, Clements JA: Nonionic polymers reverse inactivation of surfactant by meconium and other substances. Am J Respir Crit Care Med 1999;159:1391-1395.
147 Kobayashi T, Ohta K, Tashiro K, Nishizuka K, Chen WM, Ohmura S, Yamamoto K: Dextran restores albumininduced surface activity of pulmonary surfactant extract. J Appl Physiol 1999;86:1778-1784.

148 Lu KW, Taeusch HW, Robertson B, Goerke J, Clements JA: Polymersurfactant treatment of meconiuminduced acute lung injury. Am J Respir Crit Care Med 2000;162:623-628.

149 Erasmus ME, Hofstede GJ, Petersen AH, Batenburg JJ, Haagsman HP, Bambang Oetomo S, Prop J: SP-A-enriched surfactant for treatment of rat lung transplants with SP-A deficiency after storage and reperfusion. Transplantation 2002;73:348-352.

150 Lu K, Goerke J, Clements JA, Taeusch HW: Hyaluronan decreases surfactant inactivation in vitro. Pediatr Res 2005;57:237-241.

151 Lu K, Goerke J, Clements JA, Taeusch HW: Hyaluronan reduces surfactant inhibition and improves rat lung function after meconium lung injury. Pediatr Res 2005;58:206-210.

152 Ochs M, Schüttler M, Stichtenoth G, Herting E: Morphological alterations of exogenous surfactant inhibited by meconium can be prevented by dextran. Respir Res 2006;7:86:1-8.

153 Von Bismarck P, Klemm K, Garcia Wistädt CF, Winoto-Morbach S, Uhlig U, Schütze S, Uhlig S, Lachmann B, Krause MF: Surfactant "fortification" by topical inhibition of nuclear factor-?B activity in a newborn piglet lavage model. Crit Care Med 2007;35:2309-2318.

154 Von Bismarck P, Garcia Wistädt CF, Klemm K, Winoto-Morbach S, Uhlig U, Schütze S, Adam D, Lachmann B, Uhlig S, Krause MF: Improved pulmonary function by acid sphingomyelinase inhibition in a newborn piglet lavage model. Am J Respir Crit Care Med 2008;177:1233-1241.

155 Geuze HJ: A future for electron microscopy in cell biology? Trends Cell Biol 1999;9:92-93.

156 Griffiths G: Bringing electron microscopy back into focus for cell biology. Trends Cell Biol 2001;11:153-154.

157 Bendayan M: Worth its weight in gold. Science 2001;291:1363-1365.

158 Koster AJ, Klumperman J: Electron microscopy in cell biology: integrating structure and function. Nat Rev Mol Cell Biol 2003;4 Suppl:SS6-SS10.

159 Mühlfeld C, Ochs M: Functional aspects of lung structure as related to interaction with particles. In: Particle-lung interactions. 2nd ed.; Gehr P, Mühlfeld C, Blank F, Rothen-Rutishauser B, (eds): New York, Informa Healthcare, 2009; in press. 